\title{
ĐỒNG NAI THỜI SƠ SỬ: NƠI GẶP GÕ̃ CỦA NHIỀU LUỔNG VĂN HÓA
}

\author{
Lâm Thị Mỹ Dunga*
}

${ }^{a}$ Truò̀ng Đại học Khoa học Xã hội và Nhân văn, Đại học Quốc gia Hà Nội, Hà Nội, Việt Nam

"Tác giả liên hệ: Email: bebimkch@gmail.com

\section{Lịch sử bài báo}

Nhận ngày 12 tháng 01 năm 2020

Chỉnh sửa ngày 12 tháng 02 năm 2020 | Chấp nhận đăng ngày 24 tháng 02 năm 2020

\section{Tóm tắt}

Nói đến khảo cổ học sơ sủ ở miền Nam Việt Nam có lẽ không quá khi nhận định rằng vùng đất Đông Nam Bộ là địa bàn khởi đầu và xuất phát cho sụ hội tu và lan tỏa các luồng văn hóa. Các dấu vết hoạt động của nguoòi cổ nơi đây trải dài suốt tù thời đại Đồ đá - Kim khí Lịch sủ và phân bố trên nhiều dạng địa hình khác nhau. Yếu tố "Thiên thời - Địa lợi-Nhân hòa" của vùng đất Đông Nam Bộ tù lâu đã được nhiều người nghiên cứu để lý giải cho mật độ tập trung và tính chất đa dạng của các di tích khảo cổ học ở đây. Nghiên cúu này đặt vùng đất Đông Nam Bộ - Đồng Nai trong nền cảnh khu vục thời so sư (thế kỷ V TCN đển thế kỷ I-II SCN) nhằm tập trung vào một số vấn đề: Bối cảnh thời sơ sủ Việt Nam và Đông Nam Á luc địa; Các công đồng cu dân thời sơ sủ trên đất Đồng Nai; và Giá trị của di sản khảo cổ thời sơ sử và phát triển bền vũ̃ng ở Đồng Nai.

Từ khóa: Di sản khảo cổ học; Đông Nam Bộ; Đồng Nai; Phát triển bền vững; Sơ sử.

DOI: http://dx.doi.org/10.37569/DalatUniversity.10.1.638(2020)

Loại bài báo: Bài báo nghiên cứu gốc có bình duyệt

Bản quyền @ 2020 (Các) Tác giả.

Cấp phép: Bài báo này được cấp phép theo CC BY-NC 4.0 


\title{
DONGNAI IN PROTOHISTORY: THE MEETING PLACE OF MANY STREAMS OF CULTURES
}

\author{
Lam Thi My Dung ${ }^{a^{*}}$
}

${ }^{a}$ The University of Social Sciences and Humanities, Vietnam National University, Hanoi, Vietnam

*Corresponding author: Email: bebimkch@gmail.com

\section{Article history}

Received: January $12^{\text {th }}, 2020$

Received in revised form: February $12^{\text {th }}, 2020 \mid$ Accepted: February $24^{\text {th }}, 2020$

\begin{abstract}
Regarding protohistoric and early historic archeology in southern Vietnam, perhaps it is not too exaggerated to consider the Southeast Region as a starting place for the convergence and spread of cultural flows. Traces of the activities of the ancient people here stretched from the Stone Age - Metal Age - Historical Age and are distributed on many different terrains. The factors of "Clement weather - Favorable terrain - Concord among the people" in the Southeast Region have long been cited by multiple researchers to explain the concentration and diversity of archaeological relics here. This study places the Southeast Region - Dongnai in the context of the area in early history (5th century BC to $1^{\text {st }} 2^{\text {nd }}$ century $\left.A D\right)$ to focus on several issues: the context of early history of Vietnam and mainland Southeast Asia, early historic residential communities in Dongnai, and the value of archaeological heritage in early history and sustainable development in Dongnai.
\end{abstract}

Keywords: Archaeological heritage; Dongnai; Protohistoric; Southeast Region; Sustainable development.

DOI: http://dx.doi.org/10.37569/DalatUniversity.10.1.638(2020)

Article type: (peer-reviewed) Full-lengthresearch article

Copyright $\odot 2020$ The author(s).

Licensing: This article is licensed under a CC BY-NC 4.0 


\section{1. ĐÔNG NAM Á VÀ VIÊTT NAM THỜI SƠ SỬ}

\subsection{Vài nét về Đông Nam Á lục địa thời sơ sử}

Thời sơ sử ở Đông Nam Á thường được xác định trong khoảng thời gian từ thế kỷ V TCN (trước Công nguyên) đến thế kỷ V SCN (sau Công nguyên), khi đa phần các cộng đồng cư dân cổ làm nông nghiệp và sống định cư trên các địa hình đồng bằng ven sông và ven biển. Ngoài hoạt động nông nghiệp, họ còn có nhiều nghề thủ công phát triển, chế tạo, sử dụng công cụ bằng kim loại đồng và sắt ở phổ rộng, và đặc biệt, buôn bán trao đổi trở thành ngành kinh tế quan trọng đóng góp đáng kể vào phân hóa của cải, từ đó là phân biệt thân phận trong xã hội. Ở Đông Nam Á lục địa có mức độ phức hợp xã hội cao và phân tầng tinh vi hơn ở Đông Nam Ả hải đảo.

Trong thời sơ sử ở Thái Lan, qua những tài liệu khảo cổ học có thể nhận diện tính chất văn hóa của từng cộng đồng cư dân sinh sống trên các địa hình và vùng miền khác nhau. Một số tư liệu nhận diện như sau:

- Trên cao nguyên Khò Rạt, theo rìa dọc của châu thổ sông Chi và sông Mun có nhiều điểm cư trú và mộ táng với những tầng văn hóa thuộc sơ kỳ thời đại Đồ sắt được phát triển trực tiếp từ nền tảng Đồ Đồng trước đó, điển hình như các di tích Noen U Loke, Ban Chiang Hian (trung lưu sông Chi), Non Chai... Cư dân cổ ở đây sinh sống chủ yếu dựa trên sản xuất lúa gạo và đánh bắt cá. Trong đó, cả đồ đồng và đồ sắt đều được sử dụng rộng rãi trong đời sống hàng ngày. Một số làng cư trú có thành đắp đất và hào bao quanh bảo vệ (Charles, 1991);

- Miền Trung Thái Lan với địa hình đồng bằng rộng lớn được bồi đắp bởi sông Chao Phrayacùng với hệ thống sông Bang Pakong ở phía đông và Mae Klong ở phía tây. Nghiên cứu những lớp cư trú thời đại Đồ sắt những năm gần đây cho thấy sự phát triển trực tiếp trên cơ sở văn hóa vật chất của thời đại Đồng thau. Nhóm di tích này có sự đa dạng lớn, những di tích thuộc thời đại Đồ sắt có các địa điểm như: Ban Don Ta Phet, Tham Ongbah, Noen Ma Kok, Ban Lum Khao, và Ban Wang Hi. Trong đó, di tích Ban Don Ta Phet có vai trò quan trọng nhất. Kết quả của ba mùa khai quật cho thấy đây là khu nghĩa địa chôn trong một thời gian ngắn và có niên đại khởi đầu khoảng thế kỷ IV TCN. Ban Don Ta Phet cung cấp một khối lượng lớn hiện vật bằng sắt, đồng, thủy tinh, và đá quý. Nhiều đồ tùy táng là sản phẩm trao đổi với bên ngoài, đặc biệt là những đồ đựng bằng đồng với hàm lượng thiếc rất cao, hạt chuỗi khắc axit, hạt chuỗi carnelian tạo hình con vật có nguồn gốc từ Ấn Độ, và khuyên tai hai đầu thú có nguồn gốc từ Việt Nam (Glover \& Glover, 1986). Địa điểm này có một khối lượng lớn hạt chuỗi các loại. Xét về số lượng, loại hình, và chất liệu của các hạt chuỗi này có thể so sánh với hạt chuỗi phát hiện được ở khu mộ táng thuộc văn hóa $\mathrm{Sa}$ Huỳnh ở Lai Nghi, huyện Điện Bàn (Quảng Nam, Việt Nam). Đặc biệt gạo và thóc cũng đã tìm thấy trong một số bát đồng ở Ban Don Ta Phet, hiện tượng này cũng phát hiện ở di chỉ Lai Nghi; 
- OỎ bán đảo Thái Lan, cảng thị Khao Sam Kaeo có vai trò đặc biệt quan trọng, đây là nơi kết nối Đông Nam Á lục địa với thế giới Ấn Độ và Trung Hoa thời sơ sử (Bellina \& Silapanth, 2006). Đồng thời, đây cũng là nơi giao lưu của nhiều nhóm cư dân văn hóa Đông Sơn, Sa Huỳnh, và Đồng Nai (Việt Nam) với các cư dân Thái Lan đồng đại. Tư liệu khảo cổ học xác định, cảng thị Khao Sam Kaeo ở bán đảo Thái Lan có niên đại khoảng 400 100 năm TCN, di tích này đóng vai trò chiến lược trong mối quan hệ giữa Ấn Độ Dương và Biển Đông. Các tư liệu khảo cổ học cũng cho thấy nhiều bằng chứng về mối quan hệ với văn hóa Ấn Độ và Hán (Trung Hoa) và mối liên hệ nội vùng. Nhiều hiện vật ở đây rất giống với các di vật ở Ban Don Ta Phet (Thái Lan) và Lai Nghi (Việt Nam). Với những tư liệu hiện biết, đây là trung tâm sản xuất và trao đổi đồ trang sức bằng đá và thuỷ tinh. Sưu tập tàn tích sinh - khảo cổ học cho thấy một số loại hạt có nguồn gốc từ Nam Á và Đông Á như đậu mung, đậu răng ngựa, và kê đuôi chồn. Ngoài ra, ở đây cũng có rất nhiều chứng cứ về việc sản xuất lúa gạo tại chỗ của cư dân sơ sử (Cristina, 2011);

- Theo Lâm (2009c), nhìn chung:

Ở Thái Lan, đặc biệt là Đông Bắc Thái Lan, ngành thủ công nghiệp khai khoáng và luyện kim đen, hay công nghệ làm muối có vai trò cực kỳ quan trọng. Đồ sắt, đồng đỏ, đồng thau, hay muối được xem là nền tảng kinh tế thúc đẩy nhanh quá trình hình thành những xã hội dạng tiền nhà nước hay Tù trưởng quốc/Lãnh chủ (Chiefdoms) của những cộng đồng dân cư tập trung đông đúc và lớn mạnh. Những tiền đề trên là cơ sở cho sự hình thành nền văn minh sớm ở Đông Bắc Thái Lan; Đây cũng là hiện tượng tương tự như ở một số khu vực khác của Đông Nam Á (đoạn 75).

Đồ đồng ở Đông Bắc Thái Lan có nhiều nét tương đồng với đồ đồng trong văn hóa Đồng Nai giai đoạn Dốc Chùa - Suối Chồn (Việt Nam).

Thời đại Đồ sắt ở Lào đáng ghi nhận nhất là những phát hiện và nghiên cứu ở cánh đồng Chum và Lao Pako. Ngoài ra, một số nghiên cứu khác về giai đoạn Đồ Sắt như địa điểm Sepon - là mỏ đồng vàng ở nơi giáp ranh giữa ba huyện Vilabouly, Sepon, và Boualapha (tỉnh Savanakhet). Đây là nghiên cứu quan trọng bậc nhất về thời đại Kim khí ở Đông Nam Á lục địa. Những cuộc khai quật ở đây cho biết cách ngày nay khoảng 3,000 năm đã có những hoạt động khai thác đồng và đúc các thỏi nguyên liệu đồng để trao đổi với nhiều nơi khác trong khu vực Đông Nam Á (Antonino, Thongsa, Nigel, \& Viengkeo, 2014). Hoạt động khai thác tăng mạnh trong những thế kỷ cận kề Công nguyên. Bên cạnh dấu tích của khai khoáng luyện kim, tại đây còn có dấu vết cư trú và mộ táng của cư dân sơ kỳ thời đại Đồ sắt cũng được xác định. Đồ đồng có nhiều nét tương đồng với đồ đồng Đông Sơn, và một số mộ chum rất giống mộ chum trong văn hoá Sa Huỳnh (Việt Nam). Nghiên cứu gần đây nhất cho biết những chiếc qua đồng được làm tại chỗ (Mélissaet \& ctg., 2019). Thông qua địa điểm Sepon có thể giúp tìm hiểu nguồn nguyên liệu đồng mà cư dân cổ Đồng Nai dùng để chế tạo công cụ và vũ khí qua phân tích đồng vị chì. 
Tại Campuchia cũng đã phát hiện vài chục địa điểm khảo cổ học thời tiền sử. Trong giai đoạn sơ sử, nghiên cứu rất đáng chú ý là địa điểm Minot ở tỉnh Kompuong Cham. Các di tích ở đây là dạng thành tròn và tầng văn hóa dày, trong tầng văn hóa phát hiện nhiều đồ đá và gốm mảnh, và niên đại của di tích là từ $2,130 \pm 100 \mathrm{BP}$ (Before Present) đến $1,150 \pm 100 \mathrm{BP}$ (Carbonnel, 1979). Loại hình di tích này đã phát hiện nhiều ở tỉnh Bình Phước (Việt Nam) (Nguyễn, 2002). Gần đây, ở Campuchia còn có hai phát hiện rất quan trọng khác như sau:

- Phát hiện thứ nhất là ở Angkor Borei thuộc tỉnh Takeo, miền Nam Campuchia. Ở Angkor Borei, lớp cư trú dưới cùng được xác định thuộc thời đại Đồ sắt sớm, nhưng việc xác định niên đại cho di tích chủ yếu dựa trên đồ gốm. Lớp văn hóa sớm ở Angkor Borei cho thấy cơ tầng văn hóa sơ kỳ Sắt ở đây cũng như ở nhiều vùng khác của Đông Nam Á đã đóng vai trò nền tảng cho sự hình thành các xã hội có tính phức hợp cao và sự hội nhập của các cộng đồng cư dân thời đại Kim khí vào mạng lưới trao đổi những mặt hàng có giá trị biểu trưng cao, và thể hiện được thân thế địa vị xã hội (Miriam, 2006);

- Phát hiện thứ hai là ở tỉnh Prey Veng. Theo Lâm (2020):

Trong hai mùa khai quật ở Prohear, các nhà khảo cổ học đã phát hiện 52 ngôi mộ, nhưng phần lớn diện tích của di tích này đã bị những người đào trộm đồ cổ tàn phá tan hoang. Kết quả khai quật đã tìm thấy 500 đồ tùy táng, 2,700 hạt chuỗi, và hàng nghìn mảnh gốm. Niên đại của địa điểm Prohear là khoảng 2,000 năm $\mathrm{BP}$ và có thể kéo dài đến thế kỷ III-IV SCN. Nghiên cứu so sánh cũng cho thấy, những hiện vật khảo cổ ở đây có nét tương đồng về chất liệu và loại hình với nhiều địa điểm đồng đại như: Giồng Lớn (Bà Rịa - Vũng Tàu), Hòa Diêm (Khánh Hòa), Lai Nghi (Quảng Nam), và Gò Ô Chùa (Long An) của Việt Nam, hay Ban Don Ta Phet của Thái Lan. Nhiều trống đồng kiểu Đông Sơn cũng được tìm thấy trong các ngôi mộ. Khi nghiên cứu về các di tích và di vật này, Andreas, Vin, và Seng (2009) cũng đã đề cập đến hệ thống trao đồi trống đồng (bronze drum network) và hệ thống trao đổi đồ vàng (golden network) ở châu Á những thế kỷ trước và sau Công nguyên. Nhìn chung, nhiều vấn đề cần tiếp tục trao đổi và nghiên cứu kỹ lưỡng hơn, nhưng những địa điểm như Prohear (Campuchia), Giồng Lớn, Lai Nghi, và Hòa Diêm (Việt Nam) rõ ràng đã cung cấp nhiều cứ liệu để có thể khẳng định mức độ phát triển cao của cơ tầng văn hóa bản địa ở Đông Nam Á thời sơ sử trước khi có những cuộc tiếp xúc và giao lưu sôi động với những trung tâm văn minh lớn trên thế giới. Đáng chú ý là trống đồng Đông Sơn đã được tìm thấy trong một số ngôi mộ Prohear (Campuchia) (đoạn 1,2). 


\subsection{Thời so' sử ở Việt Nam}

\subsubsection{Văn hóa Đông Sơn}

Cho đến nay, các nhà khảo cổ đã phát hiện và nghiên cứu trên 200 di tích thuộc văn hoá Đông Sơn ở Việt Nam. Văn hoá Đông Sơn được các nhà khảo cổ học Việt Nam nhận thức dưới khái niệm một văn hoá khảo cổ và ngày càng rõ nét. Về địa bàn phân bố, các di tích này chủ yếu tìm thấy ở các tỉnh Bắc Bộ và Bắc Trung Bộ Việt Nam, cóniên đại tồn tại từ nửa đầu thiên niên kỷ I TCN đến thế kỷ I-II SCN, thuộc thời đại Đồ sắt ở Việt Nam. Văn hoá Đông Sơn có nguồn gốc bản địa và phát triển từ các di tích Tiền Đông Sơn ở ba lưu vực sông chính là sông Hồng, sông Mã, và sông Cả. Ba loại hình địa phương của văn hóa Đông Sơn cũng được xác định theo địa vực của các sông này. Chủ nhân văn hoá Đông Sơn được xác định là người Việt cổ (Nguyễn, 2019). Đối với các di tích hoặc di vật kiểu Đông Sơn ở ngoài Việt Nam có thể gọi chung là "kiểu Đông Sơn” (Dongsonlike) hay văn hoá “dạng Đông Sơn” (Dongsonoid). (2009a):

Cư dân văn hóa Đông Sơn đã đạt được nhiều thành tựu to lớn. Theo Lâm

Họ đã chiếm lĩnh các đồng bằng trên lưu vực những con sông lớn, các ngã ba sông, hay các vùng trung du, miền núi, và hải đảo. Tư liệu cho thấy, người cổ Đông Sơn đã tập trung thành từng làng rộng lớn và trù mật; Họ có trình độ luyện kim đạt đến đỉnh cao, tạo ra rất nhiều sản phẩm bằng đồng, từ những sản phẩm đơn giản đến các sản phẩm tinh xảo như trống, thạp đồng, thố đồng...; Những thao tác liên quan đến kỹ thuật làm khuôn và tạo vật pha chế hợp kim rất thành thục; Ngoài nghề luyện kim, đúc đồng thì người cổ Đông Sơn còn phát minh nghề luyện/rèn sắt. Đáng chú ý hơn là người Đông Sơn đã tiến hành một nền nông nghiệp trồng lúa nước khá rộng rãi, trồng nhiều thứ lúa, làm vườn, và chăn nuôi gia súc; Họ biết đến và phát triển một nền nông nghiệp dùng cày với những lưỡi cày bằng kim loại, kỹ thuật cày lật đất, và dùng sức kéo bằng động vật (đoạn 3,4 , và 6 ).

Trên cơ sở những thành tựu đạt được về luyện kim và nông nghiệp trồng lúa nước, hay các ngành nghề thủ công bước đầu được chuyên hóa. "Cu dân cổ Đông Sơn đã tạo được một ha tầng cơ sở vật chất và tinh thà̉n khá vĩung chắc, là nền tảng cho việc xuất hiện một nhà nước đầu tiên trên lãnh thổ Việt Nam cũng nhu khu vưc Đông Nam Á thời so sự" (Lâm, 2009a, đoạn 7). Trong các nền văn hóa thời sơ sử ở Việt Nam, chỉ có trong văn hóa Đông Sơn là tìm được dấu tích của nơi cư trú có phòng ngự, đó là Cổ Loa nơi có ba vòng thành và hào bao bọc, với cơ sở kinh tế vững mạnh. Cổ Loa thường được coi là kinh đô của nhà nước Âu Lạc thời An Dương Vương, đã có tổ chức quân đội hùng mạnh, được trang bị nhiều loại vũ khí bằng đồng và sắt, và đặc biệt là loại cung nỏ phức tạp và rất lợi hại (Trịnh, 2019).

\subsubsection{Văn hoá Sa Huỳnh (thế kỷ V TCN đến thế kỷ I-II SCN)}

Cho đến nay, có khoảng 90 địa điểm văn hóa Sa Huỳnh đã được phát hiện ở hầu hết mọi địa bàn/đia hình từ vùng rừng núi đến các đảo ven bờ thuộc các tỉnh miền 
Trung Việt Nam (Hình 1), địa bàn phân bố chính là từ Thừa Thiên Huế đến Ninh Thuận và Bình Thuận. Văn hóa Sa Huỳnh đã có 37 địa điểm được khai quật hoặc thám sát (Lâm, 2019). Những di tích của văn hóa Sa Huỳnh chủ yếu là các khu mộ táng, được phân bố đậm đặc ở các vùng đồng bằng lưu vực của các dòng sông và thưa dần ở các vùng đồi, vùng núi cao, và trên các đảo ven bờ. Một trong những "đặc trung chính của văn hoá Sa Huỳnh là hình thức táng trong chum/vò gốm lớn, chôn thăng đứng; Các táng tục thì khá đa dạng nhu hoả táng, hung tang, và cải táng. Ngoài ra, trong văn hóa Sa Huỳnh còn tìm thấy mộ huyệt đất nhung không nhiều" (Lâm, 2009d, đoạn 28) nếu so với mộ dùng quan tài gốm.

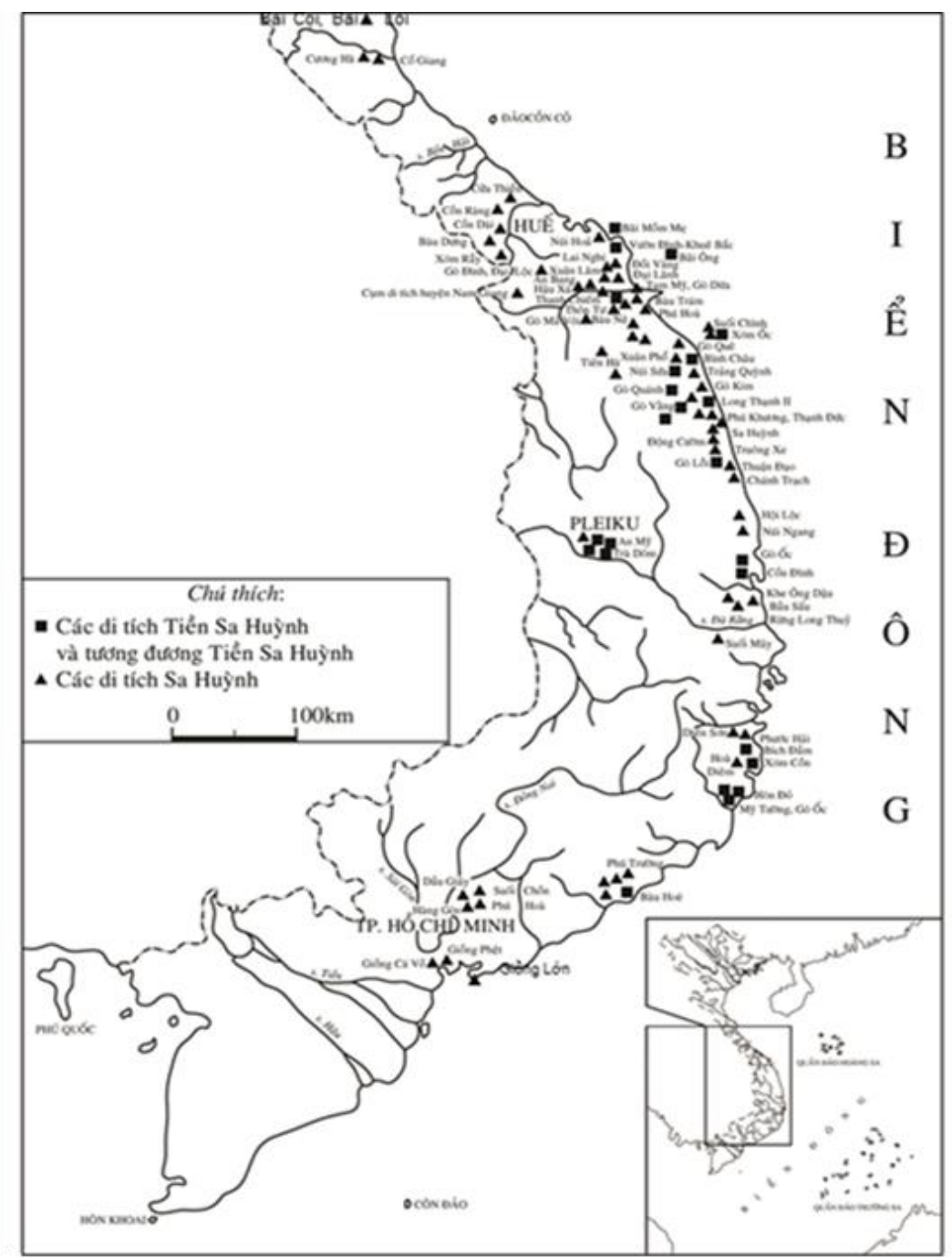

Hình 1. Bản đồ phân bố các di tích tiền - sơ sử ở miền Trung Việt Nam

Nguồn: Hán (2008, tr. 328).

${ }^{1}$ Ở khu vực các tỉnh Hà Tĩnh, Quảng Bình trước đây các học giả Pháp và gần đây các nhà khảo cổ Việt đã phát hiện một số khu mộ địa, gồm mộ chum và mộ đất mang nhiều đặc điểm với táng thức và táng tục của văn hoá Sa Huỳnh bên cạnh một số đồ đồng Đông Sơn. Tỉnh Quảng Trị có khá nhiều những phát hiện ngẫu nhiên về đồ đồng Đông Sơn, nhưng cho tới nay chưa thấy di tích mộ chum kiểu Sa Huỳnh. Mộ chum kiểu Sa Huỳnh cũng được tìm thấy ở Tây Nguyên, Đông Nam Bộ và một số đảo ở miền Nam Việt Nam. 
Dựa vào những dấu tích khảo cổ học, dữ liệu môi trường sinh thái, và so sánh dân tộc học nhận thấy các cộng đồng cư dân cổ Sa Huỳnh có cơ cấu kinh tế đa dạng, kết hợp giữa kinh tế sản xuất, kinh tế khai thác, sản xuất thủ công, và trao đổi buôn bán. Buôn bán bằng đường biển và đường sông có vai trò đáng kể đóng góp vào nền kinh tế của cư dân Sa Huỳnh. Theo Lâm (2014):

Thông qua những tư liệu vật thật và thư tịch có thể thấy, từ những thế kỷ III-IV $\mathrm{TCN}$, vai trò của biển Đông Nam Á đã có những tham gia vào con đường hàng hải quốc tế nối liền các vùng Địa Trung Hải, Ần Độ và Đông Nam Á. Các tư liệu ghi nhận từ những thế kỷ III TCN đến thế kỷ III SCN, trên bờ biển của các nước Đông Nam Á, dấu ấn về sự tham gia tích cực vào Con đường Tơ lụa phía Nam (Southern Silk Road) càng rõ nét. Có thể nói, đây chính là con đường trao đổi trên biển nối các đế chế La Mã xa xôi với Trung Hoa; Chính mạng lưới trao đổi trên là tiền đề quan trọng dẫn đến những thay đồi về kinh tế - chính trị - văn hoá trong khu vực, với một cơ cấu kinh tế đa dạng và đa ngành thích ứng với điều kiện địa lý tự nhiên và nhân văn (đoạn 22).

Các cộng đồng cư dân Sa Huỳnh có nền nông nghiệp đủ đáp ứng nhu cầu lương thực, khai thác tài nguyên rừng, núi, và biển, và trao đồi hàng hoá qua đường bộ, sông, và đặc biệt là bằng đường biển. Cơ sở vật chất giàu có cùng nền tảng tinh thần vững chắc của các cộng đồng cư dân Sa Huỳnh là nguồn lực cơ bản hình thành những nhà nước sớm Lâm Ẩp, kiểu Lâm Âp, và tạo dựng liên minh các tiểu quốc Champa từ những thế kỷ sau Công nguyên.

\subsubsection{Các văn hóa so kỳ thời đại Đồ sắt miền Nam Việt Nam}

Các di tích sơ kỳ thời đại Đồ sắt phân bố trên cả năm tiểu vùng thuộc ba khu vực là cao nguyên đất đỏ, đất xám phù sa cổ, và đồng bằng cửa sông, gồm có bảy nhóm như sau:

- Nhóm 1: Nhóm di tích văn hóa Dốc Chùa, nhóm này gồm các di tích Dốc Chùa lớp trên (Tân Uyên, Bình Dương) và Suối Chồn khu II (Xuân Lộc, Đồng Nai);

- Nhóm 2: Nhóm di tích Sa Huỳnh Đồng Nai hay còn gọi là nhóm di tích Sa Huỳnh Nam. Đây là nhóm mộ chum chịu nhiều ảnh hưởng của văn hóa $\mathrm{Sa}$ Huỳnh, gồm các di tích: Phú Hòa, Dầu Giây, Hàng Gòn (Xuân Lộc, Đồng Nai), và Suối Chồn khu I;

- Nhóm 3: Nhóm di tích phát triển theo tuyến Giồng Cá Vồ, Giồng Phệt lên Giồng Lớn. Đây là nhóm di tích mộ chum cũng chịu ảnh hưởng của văn hóa Sa Huỳnh (Hình 2a). Những di vật ở đây có nhiều nét tương đồng với các di vật cùng loại trong văn hóa Sa Huỳnh. Các di tích tiêu biểu gồm: Giồng Cá Vồ và Giồng Phệt (Cần Giờ, TP. Hồ Chí Minh) và Giồng Lớn (Long Sơn, Bà Rịa - Vũng Tàu). Các di vật tùy táng hay di vật liên quan đến hoạt động tín ngưỡng cũng khá đa dạng, như: Bát bồng, đồ minh khí, mô hình tháp... (Hình 2b); 
- Nhóm 4: Nhóm di tích Bưng Bạc và Bưng Thơm (Bà Rịa - Vũng Tàu). Đây là nhóm di tích tương đối biệt lập với các di tích cùng thời ở Nam Bộ cả về không gian phân bố và đặc trưng di vật;

- Nhóm 5: Di tích Gò Cây Tung, nhóm này hiện nay chỉ mới có một di tích Gò Cây Tung (Tịnh Biên, An Giang);

- Nhóm 6: Nhóm di tích Gò Cao Su, Lò Gạch, và Gò Ô Chùa. Nhóm này gồm các di tích Gò Cao Su, Lò Gạch, và Gò Ô Chùa lớp dưới (Long An) (Vũ, 2008);

- Nhóm 7: Gồm những di tích ở khu vực đảo ven bờ và xa bờ từ tỉnh Bà Rịa Vũng Tàu đến Kiên Giang.
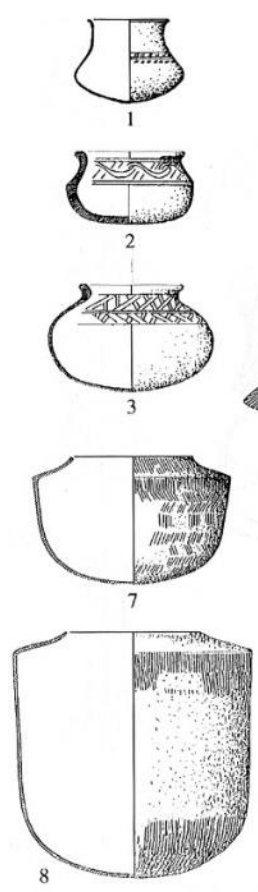
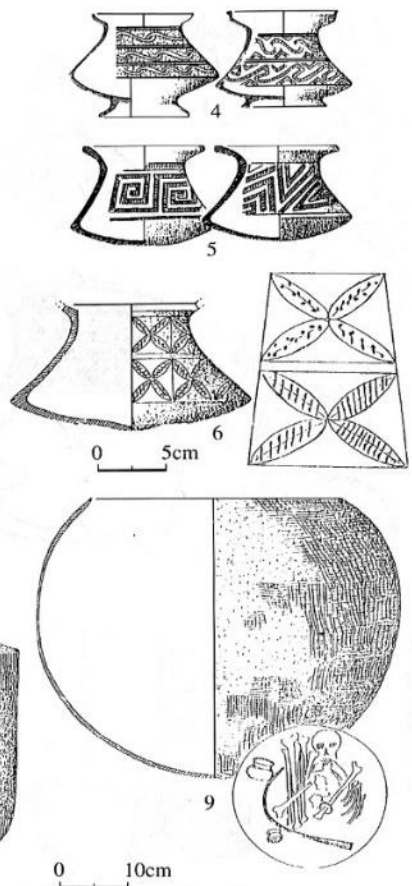

(a)

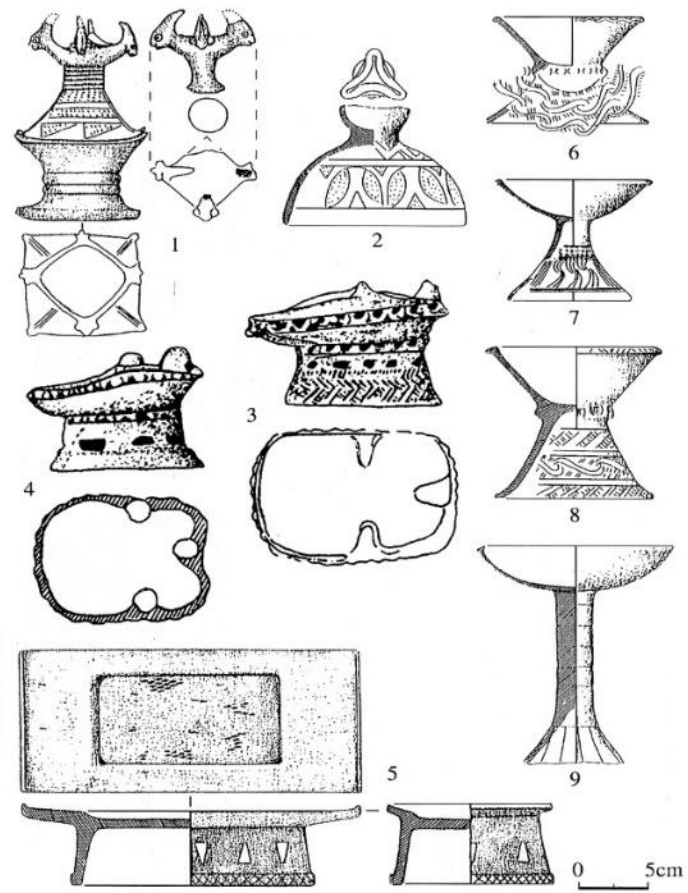

(b)

Hình 2. Nồi, chum gốm, và đồ gốm Giồng Cá Vồ

Ghi chú: a) là nồi và chum gốm; b) là đồ gốm;

Trong đó: $\mathrm{a} 1$ - a3 là nồi; $\mathrm{a} 4$ - a6 là bình kiểu Sa Huỳnh; và $\mathrm{a} 7$ - a9 là chum mộ; b1 là mô hình tháp; b3 và b4 là cà ràng minh khí; b5 là khay đựng; và b6 - b9 là bát bồng Nguồn: Hán (2008).

Nhìn chung, theo Lâm (2009b):

Các cộng đồng cư dân giai đoạn sơ kỳ Đồ sắt ở Nam Bộ thường sống tập trung thành những làng định cư lớn ở ngã ba các con sông hoặc ven biển. Ngoài ra, họ còn cư trú nơi có các doi đất cao trên bậc thềm phù sa cổ được thành tạo bởi các 
dòng sông; hay cũng có các làng định cư ở những vùng sình lầy ngập mặn với hệ thống nhà sàn gỗ (đoạn 12).

Cư dân cổ thực hành những loại hình táng thức khác nhau như: Mộ đất, mộ dùng chum vò gốm, gố, và trống đồng làm quan tài mai tang, và đặc biệt là mộ cự thạch - trác thạch mà những vùng văn hóa khác ở Việt Nam chưa thấy.

\section{CÁC CộNG ĐỒNG CƯ DÂN THỜI SƠ SỬ TRÊN ĐẤT ĐỒNG NAI}

Như đã trình bày ở trên, các cư dân thời sơ sử thường "sống tập trung thành các làng định cu lâu dài ven các dòng sông hoặc ven biển, hay các doi đất cao trên bậc thềm phù sa cổ các dòng sông" (Lâm, 2009b, đoạn 12) (Hình 3). Bên cạnh đó, ở những vùng sình lầy ngập mặn còn phát hiện các di tích tiêu biểu như: Bưng Bạc, Bưng Thơm, hay Rạch Lá... với hệ thống nhà sàn gỗ đặc trưng trên vùng sình lầy.

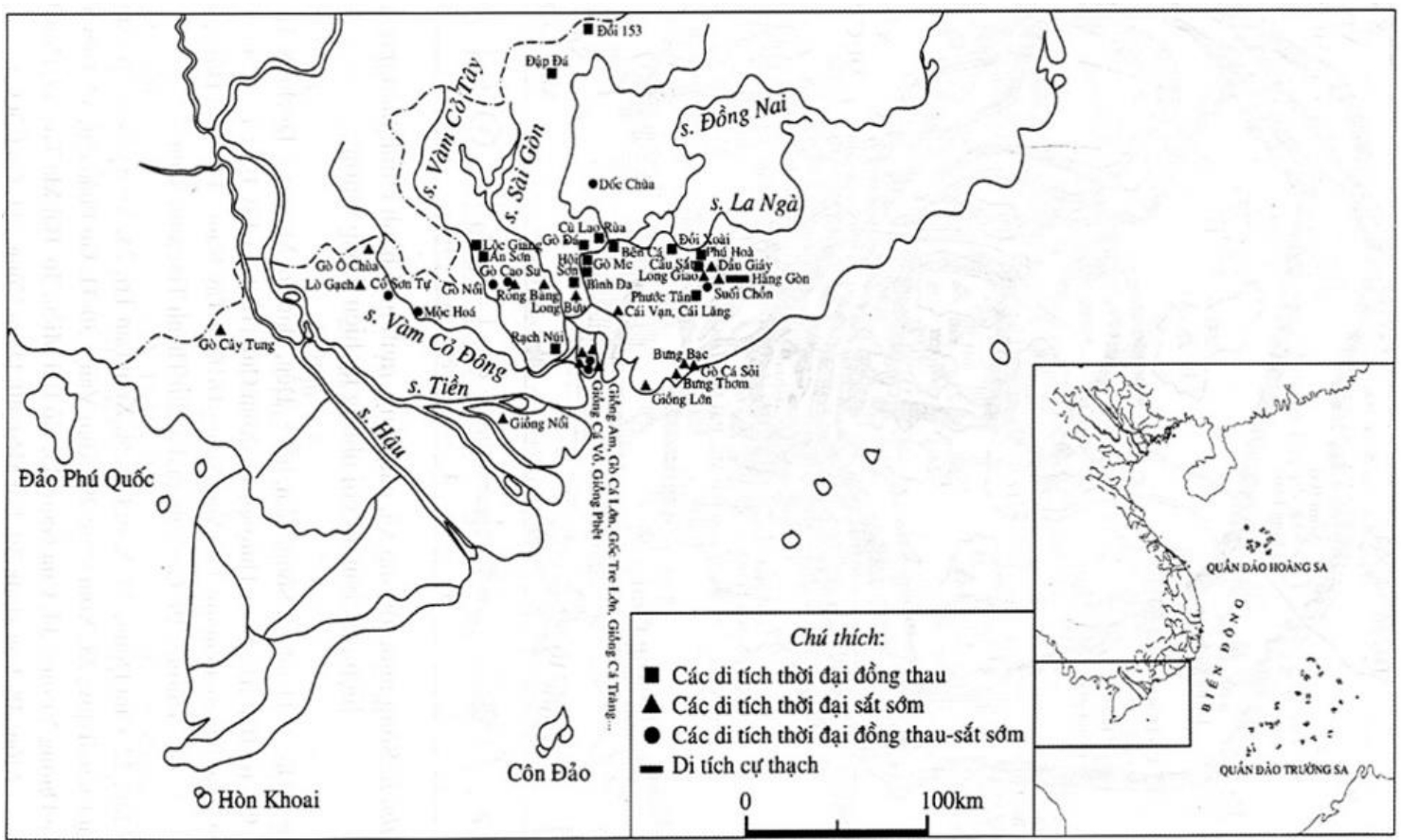

Hình 3. Các di tích thời đại Kim khí ở Nam Bộ

Nguồn: Hán (2008, tr. 329).

Những hình thức chôn cất người chết cũng khá đa dạng, bên cạnh truyền thống chôn mộ huyệt đất là mộ dùng chum vò gốm làm quan tài mai táng và loại mộ sử dụng các tảng đá lớn để xây dựng hầm mộ. Cho đến nay, loại hình di tích này chỉ được phát hiện ở Đồng Nai, là loại mộ được làm bằng các phiến/trụ đá có kích thước lớn và được xác định chắc chắn thuộc sơ kỳ thời đại Đồ sắt với cấu trúc quy chuẩn và bộ di vật tương ứng kèm theo.

Nhóm cư dân, chủ nhân của những làng cư trú trên đồng bằng cửa sông Đồng Nai, nơi giao thủy nước mặn và ngọt, chịu ảnh hưởng của chế độ thủy triều, những dấu vết cư trú được tìm thấy ở địa bàn của huyện Nhơn Trạch hiện nay. Những làng cổ này 
thuộc vào hệ thống cư trú ở loại hình sinh thái ngập mặn thuộc các tỉnh Đồng Nai, Bà Ria - Vũng Tàu, và TP. Hồ Chí Minh, kéo dài trong thời đại Kim khí (từ 3,000 năm $\mathrm{BP}$ đến sau 2,000 năm $\mathrm{BP}$ ), với những khu cư trú, mộ táng, và cảng thị, như: Công xưởng Cái Vạn, Rạch Lá, Cái Lăng, Bưng Thơm, Bưng Bạc, Giồng Lớn, Giồng Cá Vồ...

Tại làng cổ Cái Lăng, thuộc xã Long Thọ, huyện Nhơn Trạch, tỉnh Đồng Nai, hiện nay, các di tích và di vật được phát hiện vào năm 1977, đây là địa điểm đã được khảo sát nhiều lần, sau đó được khai quật lần đầu vào năm 2000 và khai quật lần thứ hai vào năm 2003. Nơi đây là dạng di tích cư trú nhà sàn trên địa hình ngập mặn kế thừa và phát triển kiểu cư trú Cái Vạn và Rạch Lá cận kề nhưng có niên đại sớm hơn. Tại lần khai quật thứ nhất, những cọc gỗ nhà sàn với một đầu được đẽo nhọn và có những ngàm khoét đã được tìm thấy. Hiện vật từ nhiều chất liệu đá, gỗ, đồng, thủy tinh, và mã não. Các nhà nghiên cứu cho rằng Cái Lăng có thể có niên đại cách ngày nay 2,500 năm (Bùi, Nguyễn, \& Đặng, 2017, tr. 101). Với hai niên đại từ gỗ, được xác định bằng phương pháp Carbon phóng xạ (C14), là 2,230 \pm 55 năm $\mathrm{BP}$ và $1,900 \pm 90$ năm $\mathrm{BP}$, cùng sự hiện diện của đồ mã não và thủy tỉnh, có thể cho rằng niên đại 2,500 năm $\mathrm{BP}$ là niên đại khởi đầu của cư trú, còn kết thúc có thể vào thế kỷ I-II SCN như nhận định của những người khai quật lần thứ hai năm 2003.

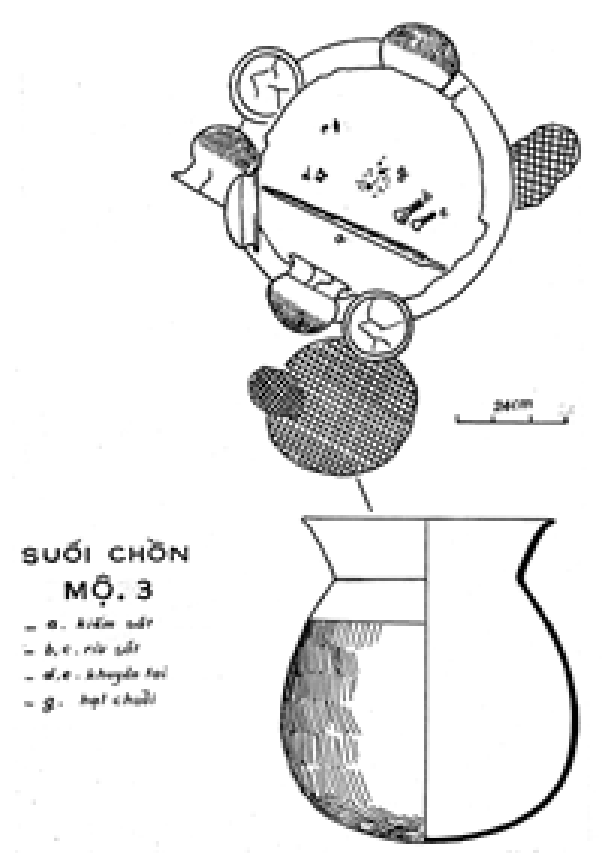

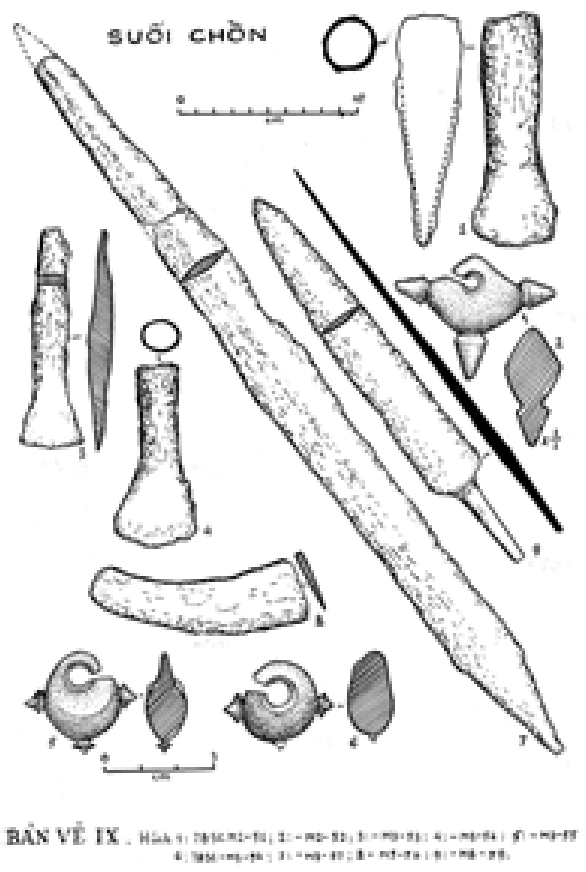

\section{Hình 4. Mộ chum và đồ tùy táng trong mộ ở di chỉ Suối Chồn}

Nguồn: Vũ (1991).

Nhóm cư dân chủ nhân các mộ chum vò chủ yếu sống ở vùng gò đất đỏ basalt ven sông Đồng Nai. Các khu mộ chum gồm Dầu Giây, Hàng Gòn 9 (còn gọi là Suối Hàng Gòn hay Suối Đá), Phú Hòa, và Suối Chồn (Hình 4). Từ cụm nghĩa địa này, đã có 108 ngôi mộ được phát lộ và nghiên cứu, các quan tài bằng gốm dạng chum, vò, và nồi chôn thẳng đứng, đáy một số mộ có đá kè và có nhiều khả năng tại mỗi nghĩa địa đã có 
một quy hoạch từ trước, và mộ chôn trong một khoảng thời gian gần nhau nên hầu như không thấy hiện tượng mộ xếp chồng và cắt phá nhau. Theo nhiều nhà nghiên cứu, táng tục phổ biến ở đây là hỏa thiêu (dựa vào dấu vết còn lại như tro, than củi, và xương vụn), còn đối với trẻ em thì dùng tục hung táng và cải táng. Những khu nghĩa địa và cư trú này, theo đa số các nhà nghiên cứu, thuộc về truyền thống văn hóa Sa Huỳnh, mà cụ thể là loại hình phía nam của văn hóa Sa Huỳnh cùng với nhóm di tích mộ chum ở Khánh Hòa, Ninh Thuận, và Bình Thuận. Tuy nhiên cũng có những ý kiến cho rằng cụm di tích mộ chum vùng Xuân Lộc thuộc giai đoạn cuối cùng hay đỉnh cao của văn hóa Đồng Nai (hay văn hóa Dốc Chùa) (Phạm, 1985). Trên cơ sở nghiên cứu những tài liệu sắt sớm ở Đồng Nai, có thể nhận thấy rằng mộ chum thời đại sắt sớm ở Đồng Nai là một bộ phận cấu thành của văn hóa $S a$ Huỳnh, nhưng có nguồn gốc xuất xứ từ một nền tảng bản địa là truyền thống văn hóa Đá mới - Đồng thau ở Đồng Nai. Từ một xuất xứ như vậy, trong bước đường phát triển, thời đại Sắt Đồng Nai đã tiếp thu những yếu tố mới mang đặc điểm văn hoá Sa Huỳnh. Điều này thể hiện trong một hệ thống phát triển từ Dốc Chùa (đỉnh cao thời đại đồ đồng) đến Suối Chồn II rồi Suối Chồn I (di tích cư trú) và cuối cùng là Suối Chồn I (di tích mộ táng) (Hình 1). Thời điểm cuối cùng này đã có thể được gọi là Sa Huỳnh (Lê, Phạm, \& Bùi, 1991, tr. 185).

Căn cứ trên đồ chôn theo mộ, một mặt cho thấy có sự phân hóa nhất định về của cải do số lượng không đều trong mỗi mộ, mặt khác lại cho thây mức độ phân hóa không lớn vì rất ít mộ không có đồ chôn theo. Trong nhóm đồ tùy táng, công cụ và đồ trang sức chiếm tỉ lệ lớn, còn vũ khí rất ít. Bên cạnh đồ tùy táng bằng đá, gốm, đồng, và sắt còn có đồ bằng thủy tinh, bạc, và vàng. Mức độ phân hóa của cải phản ánh cấu trúc xã hội của lãnh địa với chế độ thủ lĩnh.

Nhóm cư dân chủ nhân của cự thạch, trong thời đại Đồ sắt ở Đông Nam Bộ nói chung và trên đất Đồng Nai nói riêng, có sự sinh sống xen kẽ của nhiều cộng đồng cư dân. Trong mỗi cộng đồng, mức độ phức hợp của xã hội được thể hiện qua táng thức và nghi lễ khác nhau. Cự thạch là một dạng mộ táng với cách thức xử lý cấu trúc mộ rất độc đáo và không phổ biến rộng ở Đông Nam Á lục địa, nhưng thường gặp ở Nam Á và Đông Nam Á hải đảo. Cho tới nay, ở xã Hàng Gòn, thị xã Long Khánh, tỉnh Đồng Nai hiện diện một loại hình cự thạch (mộ đá - dạng trác thạch) có quy mô lớn và hình dáng quy chỉnh, và có nhiều cơ sở đáng tin cậy để xác định niên đại nhất trong số các cự thạch phát hiện được ở Việt Nam từ trước cho đến nay. Theo khảo tả của người Pháp khi lần đầu tiên phát hiện năm 1927, cự thạch có kiến trúc gồm hai hàng trụ bao quanh hầm mộ (Bouchot, 1927, 1929). Kiến trúc trung tâm của di tích là hầm mộ hình khối hộp chữ nhật được ghép bằng sáu tấm đá hoa cương có kích thước dài $4.2 \mathrm{~m}$, rộng $2.7 \mathrm{~m}$, và cao $1.6 \mathrm{~m}$. Sau phát hiện và nghiên cứu của Bouchot, mộ cự thạch Hàng Gòn còn có nhiều nhà nghiên cứu quan tâm và tìm hiểu về các khía cạnh: Đặc trưng, kỹ thuật xây dựng hầm mộ, hay niên đại của di tích... (Bouchot, 1929; Lê \& ctg., 1991, tr. 155-158; \& Parmentier, 1929).

Năm 1995, một cấu trúc cự thạch khác (cự thạch II) được các nhà khảo cổ học Việt Nam phát hiện, cự thạch II cách cự thạch I khoảng $60 \mathrm{~m}$ về phía đông nam và đá hoa cương cũng là chất liệu chính để làm các tấm đan và các trụ (Phạm, Nguyễn, \& Nguyễn, 2016). Vào những năm 2006 và 2007, các nhà khảo cổ học Việt Nam đã tiến 
hành điều tra tổng thể và khai quật xung quanh và trung tâm của cự thạch (Phạm \& Nguyễn, 2008). Quanh cự thạch đã phát hiện nhiều mảnh gốm cổ, dấu vết than tro, và đất cháy, đáng chú ý là phát hiện bàn mài bằng đá có lỗ đeo và hai chiếc tù và bằng đồng (Hình 5). Hầu hết đồ gốm thu thập trong quá trình khảo sát và khai quật bên trong khuôn viên và xung quanh cự thạch là những mảnh vỡ của các loại bình vò nhỏ, và bát chén có chân đế với chất liệu gốm mỏng và được làm bằng kỹ thuật cao, đó là lý do mà nhiều người đánh giá đây là những đồ mang chức năng cúng tế hay các nghi lễ tín ngưỡng.

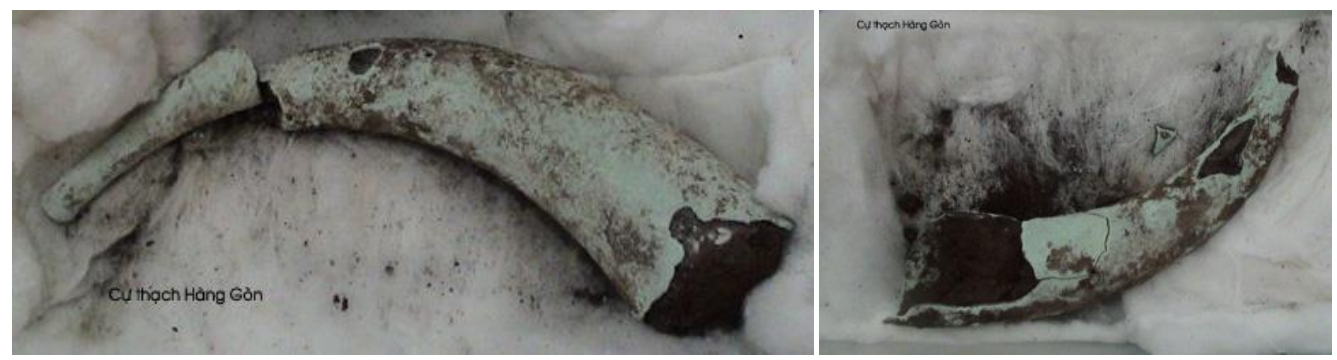

\section{Hình 5. Tù và bằng đồng ở địa điểm cự thạch Hàng Gòn, khai quật năm 2006}

Những cuộc khai quật sau này cũng cho thấy cận kề hầm mộ là nơi chế tác các tấm đan và cột đá, những tấm đan và cột đá chưa qua sử dụng cùng nhiều phế vật, mảnh tước đá, và những công cụ lao động. Số lượng đá phế liệu thu được không nhiều cho thấy người cổ đã sơ chế các tấm đan đá tại các mỏ ở nơi xa Hàng Gòn và vận chuyển về di tích để tiếp tục gia công và tạo ra những sản phẩm hoàn chỉnh. Những người khai quật cho rằng, những di tích và di vật ở đây là dấu vết của công xưởng Hàng Gòn II (Phạm \& ctg., 2016). Về niên đại của cự thạch này cũng có nhiều ý kiến khác nhau, nhưng đa số các nghiên cứu đều cho rằng hầm mộ được xây dựng và tồn tại vào khoảng thế kỷ I-II SCN (Lê \& ctg., 1991, tr. 158; Pham \& ctg., 2016; Phạm \& Nguyễn, 2008). Những tù và bằng đồng tìm thấy ở đây có nhiều khả năng có quan hệ với kho vũ khí qua đồng Long Giao (Hình 6) cách đó khoảng $5 \mathrm{~km}$ với tư cách là một phần tổ hợp vũ khí của chiến binh. Mới đây khi làm sạch hai hiện vật tù và này, người ta đã phát hiện bên trong của một tù và (ký hiệu Hàng Gòn $\mathrm{A}$ ) có 10 mũi tên bằng đồng hình dạng tam giác dẹt với năm kiểu/dạng khác nhau về hình dáng. Những mũi tên này được cho là đồ tùy táng chôn theo chủ nhân của cự thạch (Lương \& Nguyễn, 2019).

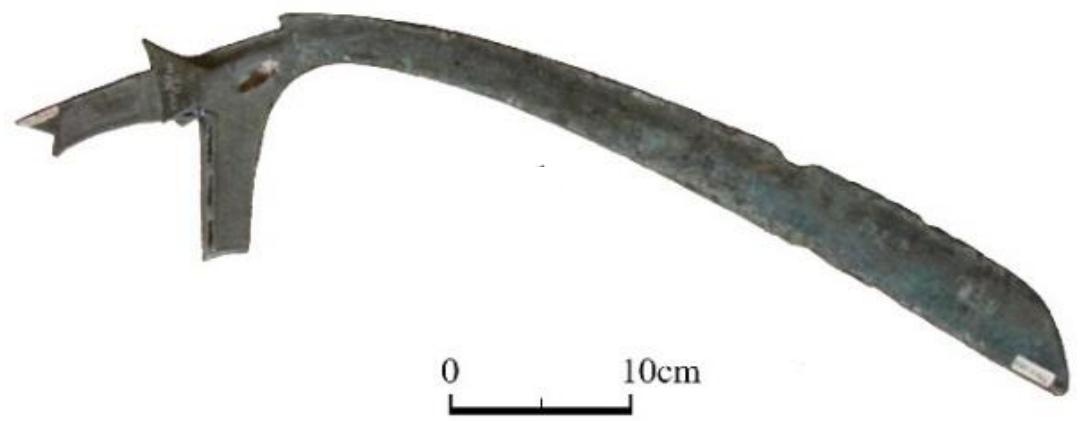

Hình 6. Qua đồng di chỉ Bàu Hòe

Nguồn: Hán (2008, tr. 438). 
Những dẫn liệu trên cho thấy, chủ nhân của cự thạch là một vị thủ lĩnh hoặc là dòng họ thủ lĩnh của xã hội lãnh địa, không những hùng mạnh về kinh tế và có đủ sức người sức của để tiêu tốn một khối năng lượng lớn cho công trình này, mà còn rất thông thạo binh nghiệp. Xã hội lãnh địa với thủ lĩnh chiến binh kiểu này, có lẽ, có những đặc điểm tương tự với các xã hội lãnh địa sở hữu trống đồng hay các chum mộ đá và gốm lớn cùng thời ở cả Đông Nam Á lục địa và hải đảo.

Như vậy, vào khoảng nửa sau thiên niên kỉ trước Công nguyên cho đến những thế kỉ đầu Công nguyên, các hệ thống di tích văn hoá cổ ở Đồng Nai/Đông Nam Bộ đã có sự phát triển trong một bối cảnh chung trước những ảnh hưởng giao lưu với thế giới Nam Đảo và Nam Á bằng cả đường biển và đường bộ. Rất có thể, mỗi con đường đều có những chuyển giao văn hóa riêng, trong đó, đường sông và đường biển đóng vai trò quan trọng. Trên cơ sở gia tăng dân số đồng thời với phát triển các nền kinh tế hái lượm, nông nghiệp, các nghề thủ công nghiệp (dệt, gốm, đúc/rèn kim loại, và chế tác đá), và buôn bán, làm ra các sản phẩm đặc sắc như: Tượng động vật; Rèn và đúc vũ khí như qua, giáo, và kiếm; Nông cụ sản xuất (Hình 7a); Hoặc ngành chế tác đồ trang sức bằng đá và gốm (Hình $7 \mathrm{~b})$. Các hoạt động sản xuất là tiền đề vật chất để sau này hình thành nên một cộng đồng cư dân đa dạng văn hoá trong thống nhất về mặt thể chế. Đó là cội nguồn cho sự ra đời của nhà nước cổ đại đầu tiên ở khu vực Nam Bộ trong những năm đầu Công Nguyên - Vương quốc cổ Phù Nam.

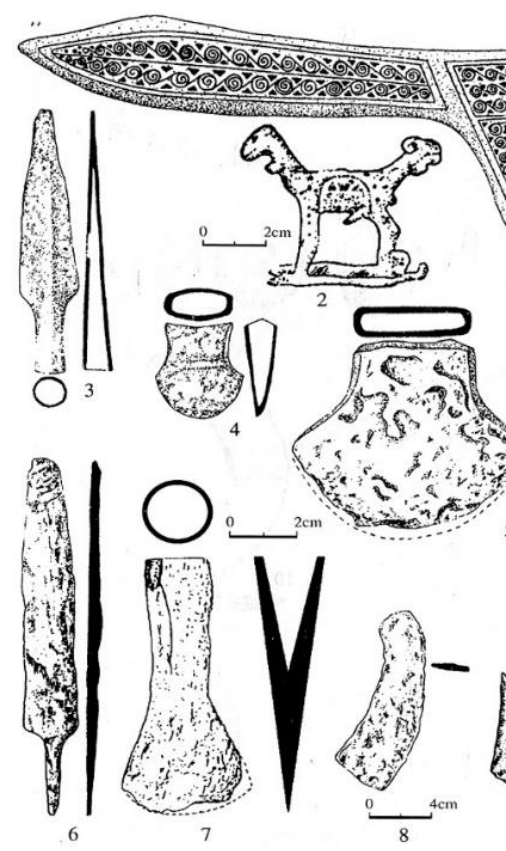

(a)

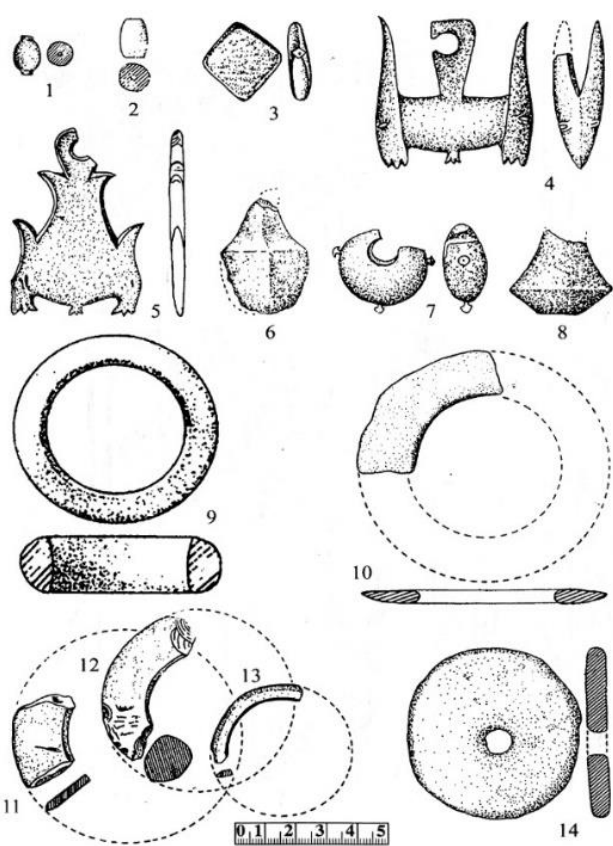

(b)

Hình 7. Hiện vật và đồ trang sức giai đoạn Kim khí ở Nam Bộ

Ghi chú: a) là hiện vật và b) là đồ trang sức;

Trong đó: a1 là qua đồng; a2 là tượng thú đồng; a3 là giáo đồng; $a 4$ và a5 là rìu đồng; $a 6$ là kiếm sắt; a7 là rìu sắt; $\mathrm{a} 8$ là liềm sắt; $\mathrm{a} 9$ là lưỡi câu bằng xương; $\mathrm{b} 1$ và b2 là hạt chuỗi đá; $\mathrm{b} 3$ là khuyên tai đá; $\mathrm{b} 4$ và b5 là khuyên tai hai đầu thú đá; b6 - b8 là khuyên tai gốm; b9 - b13 là vòng tay đá;

và b14 là phác vật đồ trang sức bằng đá.

Nguồn: Hà (1999, tr. 514-516). 


\section{GIÁ TRỊ DI SẢN KHẢO CỔ HỌC VÀ XÃ HộI ĐƯƠNG ĐẠI}

Các di sản khảo cổ học ở Đồng Nai, dựa vào định nghĩa trong Luật Di sản của nước Cộng hòa Xã hội Chủ nghĩa Việt Nam, trong Chương 1 Điều 4.2, là "sản phẩm vật chất có giá trị lịch sử, văn hóa, khoa học, bao gồm di tích lịch sử - văn hóa, danh lam thắng cảnh, di vật, cổ vật, bảo vật quốc gia" (Quốc hội, 2001). Trong Hiến chương về Bảo tồn và Quản lý Di sản Khảo cổ học của Hội đồng Quốc tế về Di tích và Công trình (International Council on Monuments and Sites - ICOMOS), Điều 1 xác định "Di sản khảo cổ $(\mathrm{DSKCH})$ là một phần của di sản vật chất mà nhờ các phương pháp khảo cổ học để thu thập được thông tin chính. DSKCH là tất cả các dấu tích về sự tồn tại của con người và bao gồm các địa điểm liên quan đến tất cả các biểu hiện của hoạt động của con người, các cấu trúc bị bỏ hoang và dấu tích của mọi thứ (bao gồm cả các địa điểm dưới đất và dưới nước), cùng với tất cả các di vật văn hóa liên quan" (ICOMOS, 1990).

Tuy nhiên, di sản khảo cổ học không chỉ là di sản vật thể, mặc dù trong các tài liệu pháp lý quốc gia và quốc tế dẫn ra trên đây chỉ chú trọng vào tính chất vật lý "sờ thấy được" và những chính sách,các chiến lược, và phương pháp bảo tồn, bảo vệ, sử dụng, và phát huy cũng chỉ ưu tiên những giá trị vật chất. Di sản khảo cổ học còn chứa đựng khía cạnh phi vật thể không sờ thấy được (intangible) và sống (living) bao gồm những giá trị tinh thần và biểu tượng của những câu chuyện và ký ức, những kỹ thuật, kỹ năng bí truyền, những tri thức dân gian, những dấu ấn có thể cả tích cực và tiêu cực của quá trình lịch sử, và chính sách văn hóa của mỗi thời kỳ và mỗi cộng đồng dân cư. Như vậy việc đánh giá giá trị di sản khảo cổ học để từ đó đưa ra chiến lược bảo tồn, sử dụng, và phát huy sẽ cần đề cập tới cả hai khía cạnh vật thể và phi vật thể. Nếu coi di sản là tài nguyên thì giá trị của tài nguyên di sản khảo cổ học theo chiều thời gian gồm: Giá trị quá khứ, giá trị hiện tại, và giá trị tương lai. Giá trị của tài nguyên di sản khảo cổ học theo nguồn gốc và tính chất gồm: Giá trị tự thân được kế thừa, giá trị tái tạo, giá trị sáng tạo của cộng đồng chủ nhân hay sở hữu di sản, và giá trị chia sẻ cho và với các cộng đồng khác.

Theo Lâm (2016):

Dựa trên những kinh nghiệm, bài học về công tác bảo tồn và phát huy giá trị di sản văn hoá trong và ngoài nước, có thể thấy, để bảo tồn và phát huy giá trị di sản khảo cổ học ở Đồng Nai nhằm phát triển theo hướng bền vững thì việc trước hết là phải khảo sát tổng thể để đánh giá được trữ lượng các di tích và di vật; Tiếp sau là phải xác định rõ những nhân tố tác động tới hiện trạng và tương lai của di tích và di vật ở cả hai góc độ khách quan và chủ quan; Tham khảo luật quốc gia và công ước quốc tế để đánh giá những kết quả đã đạt được cùng những bài học kinh nghiệm thực tế, nhằm xây dựng kế hoạch cho công tác bảo tồn và phát huy giá trị vắn hóa của các di tích và di vật. Song song với những công tác trên, vấn đề Đào tạo/Nghiên cứu - Quản lý - Khai thác/Phát huy cũng phải được quan tâm đúng mức. Trong đó, vấn đề đào tạo và nghiên cứu đi trước một bước; Đồng thời phải có chiến lược trong xây dựng nguồn dữ liệu để lập kế hoạch lâu dài và kế hoạch cụ thể trước mắt nhằm phát triển bền vững không chỉ 
trong khai thác và phát huy giá trị di sản mà cả bền vững trong đào tạo và nghiên cứu (đoạn 31).

Một trong những điều kiện quan trọng hướng đến đảm bảo sự cân bằng giữa nghiên cứu bảo tồn, trùng tu và khai thác là tái đầu tư một cách tương xứng từ nguồn lợi bán giá trị tài nguyên di sản để quay lại là tái tạo giá trị tài nguyên di sản. Mặt khác, vấn đề lựa chọn những gói sản phẩm du lịch văn hóa nhằm "khai thác nhũ̃ng giá trị Vật thể và Phi vật thể cũng cần quan tâm đến việc sáng tạo giá trị mới nhung phải dựa trên co sở khoa học và thiết kế hiện đại" (Lâm, 2016, đoạn 32). Quản lý - nghiên cứu - sử dụng tài nguyên di sản trên cơ sở hợp tác chặt chẽ giữa người triển khai/thực thi chính sách, người làm khảo cổ, người làm du lịch, và cộng đồng là đá tảng cho sự thành công để quá khứ thành tài nguyên cho phát triển hiện tại và tương lai.

\section{TÀI LIỆU THAM KHẢO}

Antonino, T., Thongsa, S., Nigel, C., \& Viengkeo, S. (2014). Ancient copper mining in Laos: Heterarchies, incipient states, or post-state anarchists? Journal of Anthropology and Archaeology, 2(2), 1-15.

Andreas, R., Vin, L., \& Seng, S. (2009). The first golden age of Cambodia: Excavation at prohear. Bonn, Germany: Thomas Muntzer Gmbh.

Bellina, B., \& Silapanth, P. (2006). Khao Sam Kaeo and the Upper Thai Peninsula: Understanding the mechanisms of early trans - Asiatic trade and cultural exchange. In E. A. Bacus, I. C. Glover, \& V. C. Pigott (Eds.), Uncovering Southeast Asia's past (pp. 379-392). Singapore: National University of Singapore Press.

Bouchot, J. (1927). Les fouilles (de Xuân Lộc). BSEI, 2(2), 155-156.

Bouchot, J. (1929). Quelques notes en marge de la delcouverte de Xuân Lộc. BSEI, 4(2), 114-124.

Bùi, C. H., Nguyễn, K. T. K., \& Đặng, N. K. (2017). Khảo cổ học Nam Bộ thời tiền sủ. Hà Nội, Việt Nam: NXB. Khoa học Xã hội.

Carbonnel, J. P. (1979). Recent data on the Cambodian neolithic: The problem of the cultural continuity in Southern Indochina. In R. B. Smith, \& W. Watson, (Eds.), Early South East Asia (pp. 223-226). New York, USA: Oxford University Press.

Charles, H. (1991). The archaeology of mainland Southeast Asia: From 10,000BC to the fall of Angkor. Cambridge, UK: Cambridge University Press.

Cristina, C. (2011). Rice in Thailand: The archaeobotanical contribution. Rice, 4(3), 114-120.

Glover, I. C., \& Glover, E. A. (1986). Ban Don Ta Phet: The 1984-85 excavation. In I. C. Glover, \& E. A. Glover, (Eds.), Southeast Asian archaeology (pp. 139-184). Oxford, UK: B.A.R. International.

Hán, V. K. (2008). Co sở khảo cổ học. Hà Nội, Việt Nam: NXB. Đại học Quốc gia Hà Nội. 
Hà, V. T. (1999). Khảo cổ học Việt Nam (Tập 2). Hà Nội, Việt Nam: NXB. Khoa học Xã hội.

ICOMOS (1990). Charter for the protection and management of the Archaeological Heritage. Retrieve from http://wp.icahm.icomos.org/wpcontent/uploads/ 2017/01/1990-Lausanne-Charter-for-Protection-and-Management-of Archaeological-Heritage.pdf.

Lâm, T. M. D. (2009a). Văn hóa Đông Sơn. Được truy lục từ http://dzunglam. blogspot.com/2009/09/van-hoa-ong-son.html.

Lâm, T. M. D. (2009b). Văn hóa Đồng Nai. Được truy lục từ http://dzunglam. blogspot.com/2009/09/van-hoa-ong-nai.html.

Lâm, T. M. D. (2009c). Bối cảnh Đông Nam Á thời Tiền sủ̉ (4). Được truy lục từ http://dzunglam.blogspot.com/2009/09/boi-canh-ong-nam-va-ong-nam-thoitien_23.html.

Lâm, T. M. D. (2009d). Úng dụng phương pháp và lý thuyết của khảo cổ học hiện đại trong nghiên cứu khảo cổ học Việt Nam: Vấn đề và Triển vong. Được truy lục từ http://dzunglam.blogspot.com/2009/12/lien-nganh-trong-nghien-cuu-khao-cohoc.html.

Lâm, T. M. D. (2010). The first Golden Age of Cambodia: Excavation at Prohear (Thời kỳ Vàng đầu tiên ở Campuchia: Khai quật Prohear) - Giới thiệu sách. Được truy lục từ http://dzunglam.blogspot.com/2010/03/first-golden-age-of-cambodiaexcavation.html.

Lâm, T. M. D. (2014). Giao thương thời tiền, sơ sử trên Biển Đông qua tài liệu khảo cổ hoc. Được truy lục từ http://dzunglam.blogspot.com/2014/02/giao-thuong-thoitien-so-su-tren-bien.html.

Lâm, T. M. D. (2016). Tài nguyên Văn hoá - Nguồn tài nguyên không vô tận, không tái tạo. Được truy lục từ http://dzunglam.blogspot.com/2016/09/tai-nguyen-vanhoa-nguon-tai-nguyen.html.

Lâm, T. M. D. (2019). Phát hiện và nghiên cứu văn hóa Sa Huỳnh (1909-2019). Tạp chí Khoa hoc Đại hoc Đà Lạt, 9(3), 75-97.

Lê, X. D., Phạm, Q. S., \& Bùi, C. H. (1991). Khảo cổ Đồng Nai thời tiền sủ. Đồng Nai, Việt Nam: NXB. Đồng Nai.

Lương, C. T., \& Nguyễn, X. N. (2019). Phát hiện mói tù̀ hai hiện vật tù và di tích quốc gia đặc biệt mộ cư thạch Hàng Gòn. Bài báo được trình bày tại Hội thảo Những phát hiện mới về Khảo cổ học năm 2018, Hà Nội, Việt Nam.

Mélissa, C., Thongsa, S., Viengkeo, S., Thonglith, L., Philippe, D., Christophe, C., \& Pryce, T. O. (2019). Laos' central role in Southeast Asian copper exchange networks: A multi-method study of bronzes from the Vilabouly Complex. Journal of Archaeological Science, 109, 1-18.

Miriam, T. S. (2006). Pre-Angkorian settlement trends in Cambodia's Mekong Delta. Indo-Pacific Prehistory Association Bulletin, 26, 98-109. 
Nguyễn, L. C. (2019). Những nghiên cứu cổ nhân học quan trọng của Việt Nam (19062018). Tạp chí Khoa học Đại học Đà Lạt, 9(3), 17-55.

Nguyễn, T. Đ. (2002). Di tích đất đắp hình tròn Bình Phước (Luận án Tiến sĩ). Viện Khoa học Xã hội vùng Nam Bộ, Việt Nam.

Parmentier, H. (1929). Vestiges mégalithiques à Xuân Lộc. BEFEO, (28), 479-485.

Phạm, Đ. M. (1985). Suy nghĩ về không gian văn hóa Sa Huỳnh. Tạp chí Khảo cổ học, (3), 31-46.

Phạm, Đ. M., Nguyễn, G. H., \& Nguyễn, H. A. (2016). Hàng Gòn kỳ quan cư thạch Việt Nam. Hà Nội, Việt Nam: NXB. Khoa học Xã hội.

Phạm, Q. S., \& Nguyễn, T. H. H. (2008). Báo cáo khai quật, thăm dò di tích mộ cụ thạch Hàng Gòn năm 2007. TP. Hồ Chí Minh, Việt Nam: Trung tâm nghiên cứu Khảo cổ.

Quốc hội. (2001). Luật Di sản Văn hóa. Được truy lục từ http://vanban.chinhphu.vn/ portal/page/portal/chinhphu/hethongvanban?class_id=1\&_page $=5 \&$ mode $=$ detail \&document_id=80239

Trịnh, H. H. (2019). Kết quả nghiên cứu thành Cổ Loa (2007-2014): Tư liệu và thảo luận. Tạp chí Khoa học Đại học Đà Lạt, 9(3), 98-123.

Vũ, Q. H. (1991). Di chỉ Suối Chồn (khai quật lần thứ hai). Hà Nội, Việt Nam: Bảo tàng Lịch sử Việt Nam.

Vũ, Q. H. (2008). Vài suy nghĩ về các di tích mộ chum ở Đông Nam Bộ. Hà Nội, Việt Nam: Bảo tàng Lịch sử Việt Nam. 